\title{
Seramikte Lazer Oyma Makineleriyle Uygulanabilecek Mühürler ve Rölyefler
}

\author{
Efe TÜRKEL*
}

Özet

İnsanoğlunda boş ve temiz bir yüzey üzerinde iz bırakma dürtüsü hep var olmuştur. Bu dürtünün ister içgüdüsel, isterse bilinçli olsun eski çağlardan beri kilden yapılmış objelerin yüzeylerine çeşitli bezemeler yapılmasına da sebep olduğunu bilmekteyiz. Özellikle kilden yapılmış eşyaların kurutularak ve pişirilerek sertleştirilmesi ve üzerine bırakılan izlerin çok uzun yıllar boyunca yaşayabileceğinin öğrenilmesiyle seramik malzeme bilgi aktarımı açısından da bir tercih sebebi olmuştur. Antik çağlarda seramik yüzeylere bezemeler oluşturmak için doğal nesnelerden veya basit aletlerden faydalanılmıştır. Günümüzde ise bu bezeme uygulamaları için doğal nesneler halen kullanılmakla beraber farklı olarak pek çok malzeme seçeneği ve yardımcı unsur vardır, ancak eski çağlardaki seramikçilerle günümüzdekiler arasında amaç adına farklılıklar bulunmamaktadır. Bu çalışmada öncelikle, doğal ve el yapımı nesnelerle kurgulanan, yaş çamur üzerine baskı yöntemiyle yapılmış bezeme tekniklerinin tarihine ve çeşitlerine ilişkin kısa bilgi ve örnekler verilmiştir. Günümüz imkânları dâhilinde, vektörel yazılımlar ve lazer kazıyıcılar aracılığıyla seramik yüzeylerin bezenmesinde ve şekillendirilmesinde kullanılabilecek mühür ve rölyefli model oluşturma tekniklerine yönelik uygulama yöntemleri, bunların kendi içinde barındırdığı avantaj ve dezavantajlar üzerinde durulmuştur.

Anahtar Sözcükler: Seramik, Mühür, Rölyef, Lazer Oyma Makinesi, Vektörel Tasarım.

\section{Seals and Reliefs Applicable on Ceramics with Laser Engravers}

\section{Abstract}

The impulse of marking on an empty space has always existed for humankind. We know, this impulse caused man to produce various patterns on clay objects, consciously or instinctive. The ceramic material has become a reason for preference in transforming knowledge because of the clay objects's longtime durability in keeping traces and marks left on them, which were produced with hardening the surface by means of drying or firing process. In antiquity, natural objects or simple tools were used for making patterns on clay surfaces. In present conditions, in spite of natural objects, many materials and auxiliary elements can be used, but the aim of ancient and present ceramists is still the same. Primarily, the information and samples about history of patterns and their techniques which were made by natural objects and simple tools are demonstrated in this paper. Methods of application about the techniques of relief models and seals can be used for making patterns on ceramic surfaces by the help of vectorial design software and laser engravers are presented and their advantages and disadvantages are discussed.

Keywords: Ceramic, Seal, Relief, Laser Engraver, Vectorial Designing. 


\section{Giriş}

Çömlekçiler veya pişmiş topraktan herhangi bir eşya yapan hemen hemen her usta başlangıçta çevreden buldukları objelerle ıslak kil yüzeylere izler bırakmıştır. Bu yüzeyler kimi zaman deniz kabukları, kemik, sopa ve benzeri doğal objelerle kimi zaman ise tırnak, parmak veya el izleriyle farklı doku ve biçimlerle bezenmişlerdir. Bunun yanı sıra doğadaki nesneler işlenerek çeşitli el aletleri yapılmış veya bu nesneler ihtiyaçlar doğrultusunda çeşitli biçimlere dönüştürülerek benzer uygulamalar gerçekleştirilmiştir. Daha ileriki aşamalarda bezemelerde bir standart sağlamak için ahşap, pişmiş çamur ve benzeri çeşitli materyallerden mühürler yapılmış ve yaş çamur üzerine baskılama yöntemiyle uygulanmıştır. Estetik açıdan bakıldığında, kimi zaman mühür veya ruletle yapılmış bezeme sadece bir süsleme aracıyken, kimi zaman ise formu tamamlamak veya formu tamamen değiştirmek adına yapılmış biçimsel kaygılar içeren bir uygulama olarak değerlendirilebilir.

Yaş çamur üzerinde kullanılan mühürler temel olarak iki sınıfta toplanabilir. Bunların ilki çevremizden kolaylıkla bulabileceğimiz doğal nesneler ve yine benzer nesnelerin veya endüstriyel olarak üretilmiş bazı malzemelerin işlenmesiyle elde edilen ıstampa tipi mühürlerdir. İkincisi ise, rulet olarak da bilinen, devamlı bir desen akışı sağlayan silindirik mühürlerdir.

Seramik objelerin yüzeylerine yapılan izlerden, mühürlerin ilk kez kullanılmasına kadar geçen süreç incelendiğinde, karşımıza çıkan örneklerde hem medeniyetler tarihinin, hem de sanat tarihinin izlerini sürebilmenin mümkün olduğunu görülmektedir. Doğal nesnelerin yaş çamurun üzerine basılmasıyla oluşturulan bezeme çeşitlerinin ise seramiğin doğuşundan itibaren başladığı düşünülmektedir.

\section{Geçmişten Günümüze Seramik Yüzeylerde Baskılama Yön- temiyle Oluşturulan Bezemelere Kısa Bir Bakış}

Çimdikleme yöntemiyle veya fitil tekniğiyle yapılan çömleklerin yapımında yüzeylerde ister istemez parmak izleri kalır. Elle şekillendirilmiş ve M.0̈. 24.000'e tarihlendirilmiş olan Dolni Věstonice'de bulunan seramik figürinlerin parçalarında dahi, kasıtlı veya kasıtsız olarak kulla- nıldığı bilinmemekle beraber, parmak ve tırnak izlerine rastlanmıştır. ${ }^{1}$ Toprak kaplar, çanaklar veya çömlekler olarak tabir edilen gündelik kullanıma uygun seramiklerin en eski örneklerinin bulunduğu Japonya'daki Jōmon döneminde üretilen seramiklerin ise M.0̈. 10.000 yılına tarihlendiği ve bunların ilk örneklerinin çimdikleme yöntemiyle şekillendirildiği bilinmektedir. ${ }^{2}$ Ayrıca, fitil bezemeli olarak adlandırılan Jōmon dönemi seramiklerinin yüzeylerine dokulu iplerin basılmasıyla oluşturulan desenler de bu seramik kapların en belirgin özelliğidir (Resim 1).

Bu dekorlama üslubunun yanı sıra diğer kazılarda elde edilen seramik parçalarda da tırnak iziyle oluşturulmuş desenlere rastlanmıştır. Jōmon dönemine ait diğer parçalarda ise deniz kabuklarının kilin yüzeyine basılmasıyla oluşturulan desenler de görülmektedir (Minogue, 1996: 12). Jōmon dönemi seramikleri, hem doğal nesnelerle hem de el yapımı iplerle çamur üzerine izlerin bırakıldığı ilk seramikler olarak karşımıza çıkmaktadır.

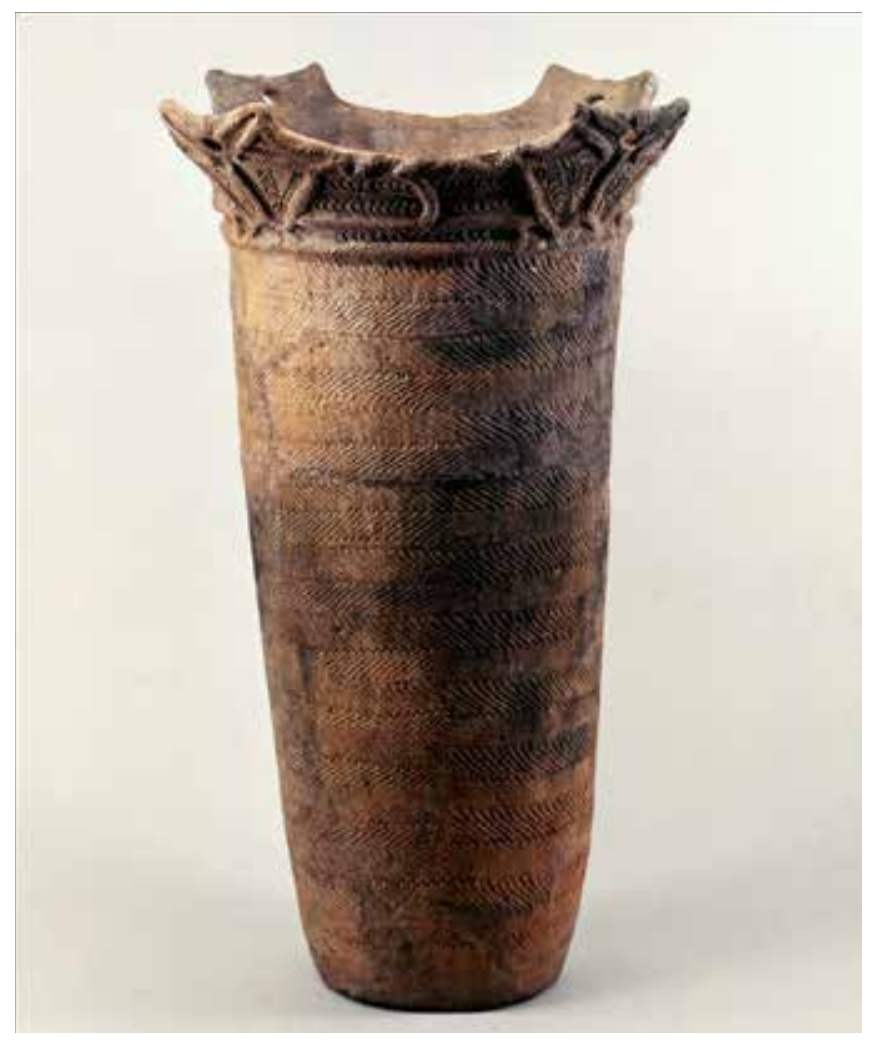

Resim 1. İp desenli ve fitillerle bezenmiş derin kap. 69,8 x 41,9 cm. Orta Jōmon Dönemi, M.Ö. 3500-2500. Metropolitan Museum of Art. Arşiv erişim numarası; 1965.268 .182 
Bu bunun gibi pek çok bezeme yöntemi diğer kültürlerde de zamanla kullanılmaya başlanmış deniz kabukları, ağaç kabukları, yapraklar ve taşlar gibi doğada rastlanılabilecek türden nesnelerle ıslak kil yüzeylerde desen oluşturma işlemi yaygınlaşmıştır, eski çağlardan beri uygulanan bu yöntem günümüze kadar kesintisiz biçimde devam etmiştir. Günümüz seramik sanatçıları dahi bu yöntemi zaman zaman çalışmalarındaki temel plastik unsur olarak kullanmakta ve sıra dışı örneklerle eserlerini oluşturmaktadır. 1970'lerin sonu ve 1980'lerin başında Macar sanatçı Imré Schrammel bulduğu ölü kuşları yaş çamur üzerine basarak bir dizi rölyef çalışması gerçekleştirerek bu sıra dışı eserlere örnek teşkil edecek türden çalışmalar sergilemiştir (Minogue, 1996: 15) (Resim 2).

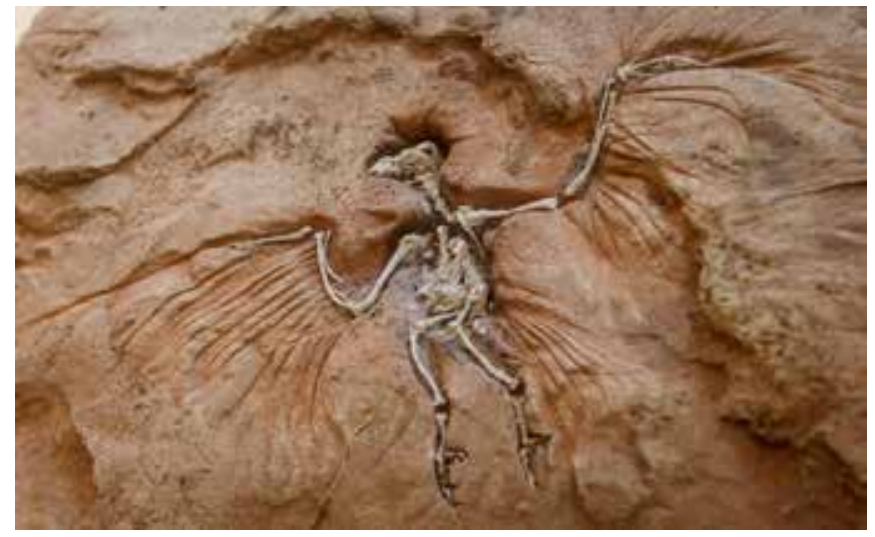

Resim 2. Imré Schrammel'in ölü bir kuşun bedenini kil üzerine basarak aktardığı çalışması.

Eski çağlardan beri doğal nesnelerle veya elleriyle çamur üzerinde izler bırakan insanlar bir adım daha ileri giderek kendi biçimlendirdikleri veya değişime uğrattıkları objeleri de aynı amaç için kullanmaya başlamışlardır. Tarihöncesi dönemden başlayarak çömlekçilerin kesilmiş ve oyulmuş tahta parçalarıyla veya kemik ve boynuzlarla kil üzerine iz bırakmak amacıyla aletler yaptığının kanıtı olan buluntular keşfedilmiştir. Arkeolog Denise SchmandtBesserat'a ${ }^{3}$ göre insanlar yaygın olarak, tüm Orta Doğu sitelerinde kil üzerine çeşitli bilgileri kayıt altına almak için semboller basmaya M.0̈. 9. binyıldan itibaren başlamışlardır (Shendge, 1983: 114). Günümüzdeki Irak topraklarında bulunan Sümerlerin yaşadığı Uruk kentinde bulunan ilk kil tablet örnekleri M.0̈. 4. binyılın sonuna ve 3. binyılın ba- şına tarihlendirilmiştir (Nicolopoulou, 1997: 208). Sümerlerin yazıyı icat etmesiyle beraber kil tabletler üzerinde uçları sivriltilmiş aletlerle yazılan ve çivi yazısı adı verilen bu yazı her ne kadar dokümanter nitelikte olsa da insanlığın yaş çamur üzerine baskı yoluyla çeşitli bilgileri içeren sembolleri işlediği önemli eserlerdir. Bunun bir sonraki evresi ise silindir şeklinde çamurun üzerinde tekrar eden desenler oluşturan ruletlerin veya başka bir deyişle silindirik mühürlere benzer aletlerin yapılması olmuştur (Minogue, 1996: 16). Bu nesneleri pişmiş topraktan yapılmış silindirik döngüye sahip yazım araçları izlemektedir. Bunların en güzel örneklerine ise Anadolu ve Mezopotamya'dan elde edilmiş buluntularda rastlamak mümkündür (Resim 3).

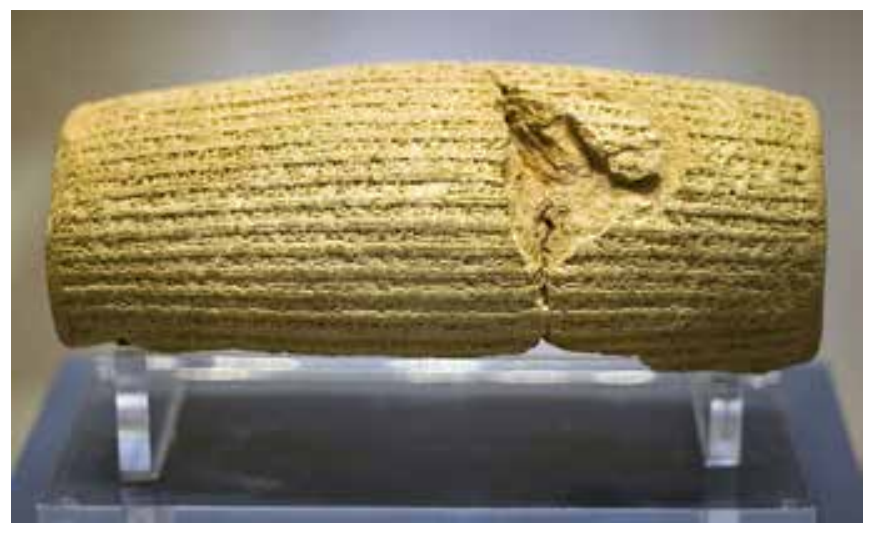

Resim 3.Kiros Silindiri, Büyük Keyhüsrev’in (II. Kiros) ilk insan hakları bildirgesi varsayılan metninin yer aldığı pişmiş topraktan yapılmış silindir, M.Ö. 539 ve sonrasına tarihlendirilmiştir.

The British Museum. Müze envanter numarası: $90920 .{ }^{4}$

Çömlekçilikte el yapımı mührün dekoratif kullanımına ait bilinen ilk örneklerine ise, Ege Denizi'ndeki Kikladik Adalarda bulunan Keros-Syros kültürüne ait seramik objelerde rastlanmaktadır (M.0̈. 2700-2200) (Minogue, 1996: 27). 'Tava' adı verilen bu seramik objelerin işlevi hakkında henüz bir fikir birliğine varılamamış olsa da Yunan arkeolog George Emmanuel Mylonas bunların sofrada kullanılan dekoratif amaçlı sunum tepsileri olduğu hakkında görüş bildirmiştir (Coleman, 1985: 191). Bu objelerin üzerindeki mühür baskılar, çamur üzerine belirli bir dekoratif kurgu oluşturmak için yapılmış işlevi olmayan biçimlerden oluşturulmuştur (Resim 4). 


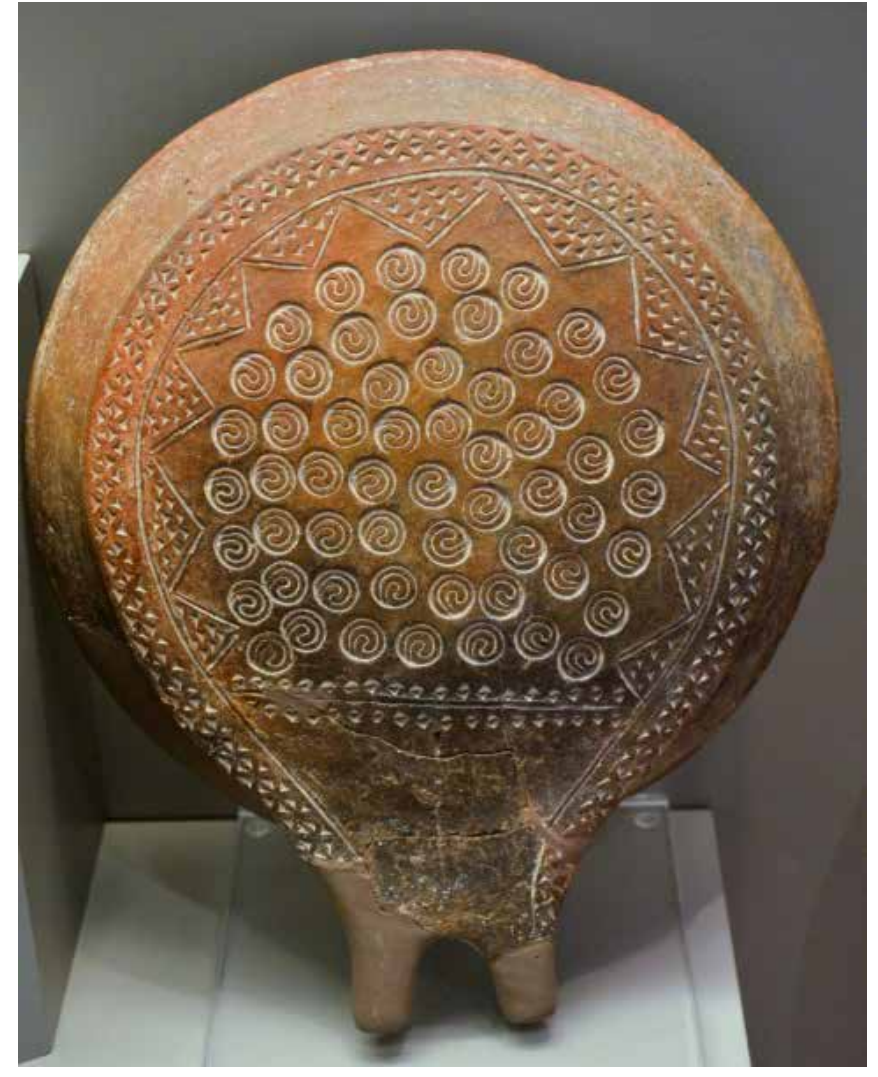

Resim 4. Syros'ta bulunmuş, üzeri dalga benzeri spirallerle bezenmiş Kikladik Tava. M.Ö. 2800 - 2300. Atina Ulusal Arkeoloji Müzesi. Envanter numarası: 5058. Fotoğraf: Dan Diffendale (2012).

El yapımı mühürlerin kullanımı binlerce yıl boyunca bahsi geçen şekilde devam etmiş, mühürlerin yaş çamur üzerine basılması yöntemi özellikle 13. ve 16. yüzyıllar arasında sıklıkla kilise, manastır ve saraylardaki yer karolarında kullanılarak farklı bir tekniğin gelişmesi sağlanmıştır. Ahşap mühürlü ve rölyefli kalıplar bu dönemde yaygınlaşmış, mühürlenmiş veya kalıba basılmış kırmızı çamurun boşluklarına tezatlık oluşturacak şekilde açık renk sıvı çamurun uygulanmasıyla tekrar eden geometrik, bitkisel ve hanedan armalı desenlerin oluşturduğu zengin bir doku elde edilmiştir (Scott, 1998: 14) (Resim 5).

Yaş çamur üzerine uygulanan baskı sadece yüzeyde çukur bir desen oluşturmaya yönelik değil aynı zamanda mührün içine yapılacak kazıma sayesinde yüzeyde kabartma etkisi oluşturan desenler yaratmak için kullanılmıştır. Bununla beraber geçmişten günümüze seramik sanatçıları kumaş, metal, plastik, karton ve benzeri endüstriyel nesne- lerin dokularını düz çamur yüzeylere bir silindir veya merdane aracılığıyla baskılayarak aktarıp, bu çamurların biçimlendirilmesiyle de farklı etkide çalışmalar yapmışlardır. Bu tip çalışmalarda yüzeydeki dokunun etkisi daha çeşitli ve vurgulu olabilmektedir (Resim 6).

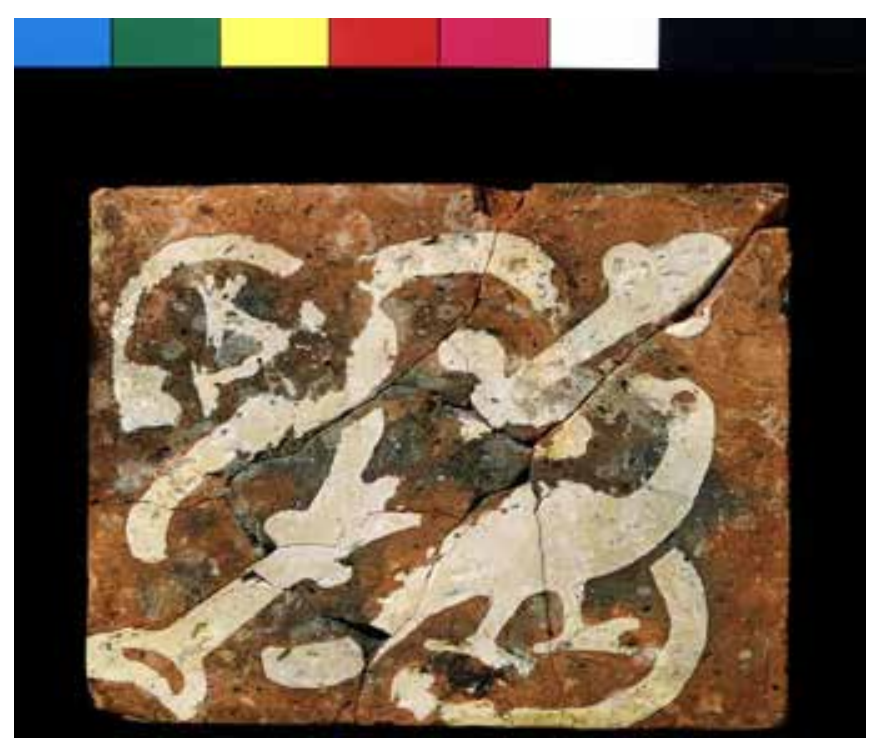

Resim 5. Bitkisel bir desenle birbirinden ayrılarak resmedilmiş iki kuş figürlü pişmiş toprak yer karosu. Desenler önce mühürle basılmış, daha sonra içi beyaz sıvı çamurla doldurulmuştur. 14 x $14 \mathrm{~cm}$ boyutlarındaki karo 1280 yılında Hampshire Hıristiyan

Kilisesi için yapılmıştır. V\&A Müzesi Koleksiyonu. Müze numarası: 1268-1892.

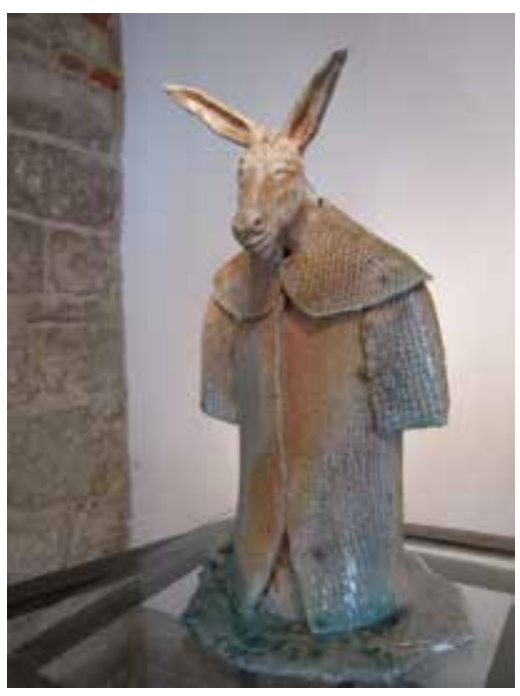

Resim 6. Dantellerin ve kumaşların kil üzerine bir merdane aracılığıyla çıkarılmasıyla farklı ve deneysel desenler elde etmek mümkündür. Efe Türkel, 'A donkey is always donkey', 25 x $11 \mathrm{x}$ $10 \mathrm{~cm}$, stoneware, tuz pişirimi, 2014. Letonya Güzel Sanatlar Akademisi Koleksiyonu (Fotoğraf: Efe Türkel). 
Günümüzde seramik sanatçısının veya tasarımcısının kullanmak istediği mühür ve rölyef etkili modellerin desenlerinin ve dokularının farklı boyutlarda değer kaybı olmaksızın tasarlamasını ve uygulamasını sağlayabilecek yardımcı teknolojiler geliştirilmiş̧ir. Bu sistem içerisinde yer alan lazer oyma makineleri ve vektörel yazılımlar kısa süreler içerisinde ıstampa mühür, silindirik mühür ve rölyefli yüzey modelleri oluşturmak açısından oldukça pratik çözümler sunabilen teknolojiler arasında yer almaktadir.

\section{Lazer Oyma Makineleriyle Seramik Yüzeyler Üzerine Uygu- lanabilecek Mühür ve Rölyef Yapım Yöntemleri}

Lazer oyma makineleri, ağırlıklı olarak kaşe, mühür ve benzeri ürünlere yönelik üretim yapan işletmelerce kullanılan ve son on yıldır ticari olarak yaygınlaşmaya başlamış cihazlardır. Marka ve model bakımından çeşitlilik gösterse de çalışma prensipleri aynıdır. Vektörel tabanlı tasarımların yapıldığı yazılımlarda gerçekleştirilen çizimlerin sayısal değerlerine göre, ihtiyaca uygun malzemenin kazınmasıyla alçak ve yüksek kotlarda desenlerin oluşturulabildiği, karmaşık olmayan bir çalışma prensibi vardır. Bu cihazlar hakkında bilgi vermeden önce tasarımların çizilmesini ve işlenmesini sağlayan vektörel tasarım yapılabilen yazılımlara ilişkin bilgileri paylaşmakta fayda vardır.

Tasarıma yönelik yazılımlar, tasarım sürecinde bizlere çizim, renk, doku, ölçülendirme, katmanlandırma ve arşiv oluşturma gibi pek çok konuda avantaj sağlar. Bu çalışmanın uygulamalarına ilişkin kullanılabilecek yazılımlara örnek olarak Adobe Illsutrator, Corel Draw, Autodesk AutoCAD, Autodesk Maya, Rhinoceros, NX Siemens gibi iki ve üç boyutlu vektörel tasarımların yapılabildiği yazılımlar gösterilebilir. Vektör tabanlı tasarımların en büyük özelliği, grafik unsurun ekran çözünürlüğünü ve renkleri ifade etmekte kullandığımız görüntüleme sistemi olan pikselden farklı olarak, her bir noktasının matematiksel değerlere sahip olması ve bundan dolayı detay kaybetmeksizin tekrar boyutlandırılabilmesidir. 5

Vektörel çizimlerin yapılabileceği yazılımlarda tasarlama yöntemi, tasarıma ve uygulamaya göre farklılıklar gösterebilir. Tasarımın tamamı başlangıcından sonuna dek yazııım ekranında gerçekleştirilebileceği gibi, bir kâğıt üzerine el ile çizildikten sonra veya fotoğraf gibi görsellerin yazılım ekranına aktarılıp işlenmesiyle de istenilen düzeye getirilebilir (Resim 7-8). Bu çalışmada örneklerle gösterilen vektörel çizimler Adobe Illustrator ve Rhinoceros programlarında gerçekleştirilmiştir.

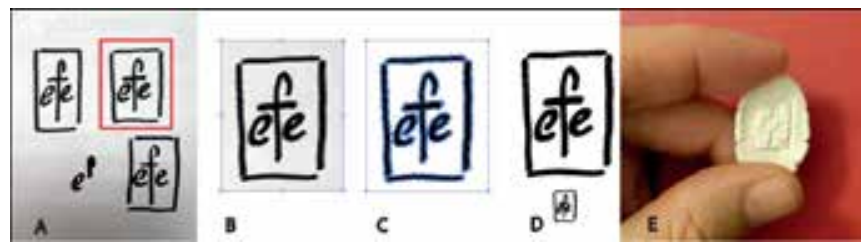

Resim 7. Mürekkepli kalemle kâğıt üzerine yapılan logonun dijital ortama aktarılarak vektörel çizime dönüştürülmesi ve mühür uygulaması (Uygulama: Efe Türkel).

Resim 7'de görülen işlemleri sırasıyla açıklamak gerekirse, A)Kâğıda yapılan çizimlerden istenilen seçilir. B) Yapılan çizim Adobe Illsutrator programına aktarıldıktan sonra 'window' komutu altında bulunan 'image trace' komutu ile seçilir ve işlenir. C) Daha sonra 'object' üst komutu altında bulunan 'expand' komutu ile çizim üzerinde kontrol noktaları aracılığıyla değişiklik yapmamızı sağlayan izlekler oluşturulur. D) Vektöre dönüştürülen çizim detay kaybı olmaksızın büyütülüp küçültülebilir. E) Logo lazer oyucuyla istenilen boyutta bir mühür olarak işlenir ve çamur üzerine uygulanabilir.

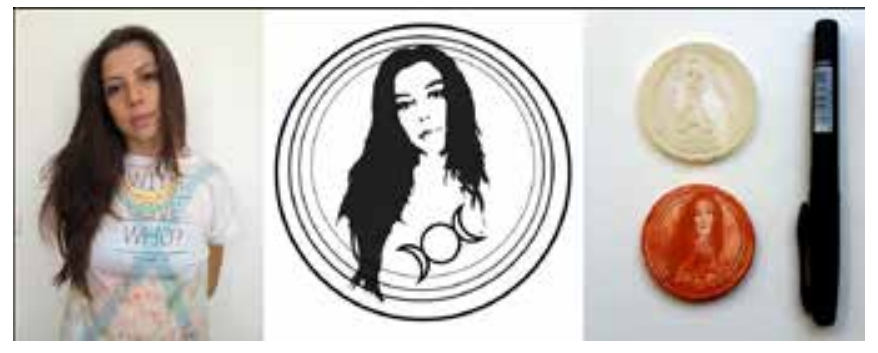

Resim 8. Bir fotoğraf aracılığıyla yapılan vektörel tasarımın pleksi malzemeden mühre dönüştürülmesi ve kil üzerine uygulandıktan sonra terra sigillata ile renklendirilmesi (Uygulama: Efe Türkel).

Resim 8'de görülen tasarımda fotoğrafın önce Adobe Photoshop programında belirli ışık ve renk değerlerinin ayarlanmasından sonra Adobe Illustrator ile Resim 7'de 
anlatılan komutlarla uygulaması gerçekleştirilir. Dijital verilerin işlendikten sonra 'pdf.' dosya uzantısında kaydedilmesi tasarımın lazer oyma makinelerinde marka gözetmeksizin okunabilmesini sağlar. Bu dosya uzantısındaki tasarımları hemen hemen her türlü yazılımda da görüntüleyebilmek mümkündür. Yazılımlar tüm bu özellikleriyle tasarım ve uygulama sürecini hızlandırarak kullanıcıya büyük avantaj sağlar.

\section{Lazer Oyma Makineleri ve İşlenen Malzemelerin Özellikle- rine Göre Oluşturulabilecek Mühür ve Rulet Tipleri}

Lazer oyma makinelerinde işlenebilecek malzemeler çeşitlidir. Örnek gösterilen çalışmalarda kullanılan lazer oyma makinesi Amerikan Epilog firmasının ürettiği 'Epilog Laser Mini' serisine ait makinedir (Resim 9). Bu ve benzeri makinelerde özelliklerine göre taş, metal, ahşap, kâğıt, kumaş, polioksimetilen, cam v.b. pek çok materyali işlemek mümkündür (Epilog, 2015). 6

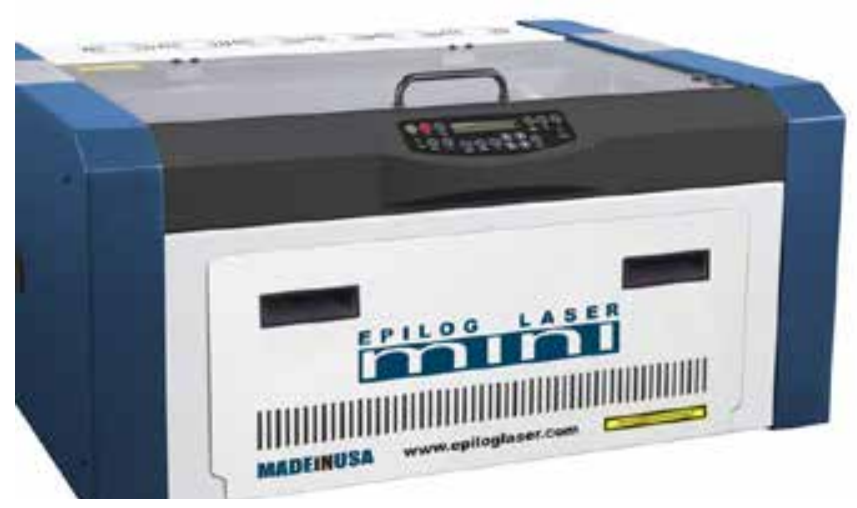

Resim 9. Epilog firmasının, $45 \times 27 \mathrm{~cm}$ çalışma tepsisine sahip mini serisi lazer oyma makinesi.

Seramik çamurun yüzeyinde kullanmaya uygun olarak işlenecek materyal tercihe bağlıdır. Metal bir yüzeyin oyulmasıyla bir mühür elde edilebildiği gibi, esnek bir malzeme olan kaşe lastiğine de bir desen işlenebilir. Burada önemli olan kıstas uygulama için doğru malzemenin tasarım sürecinde yer almasıdır. Eğer yüzeyimiz eğimli ve dokuluysa esnek bir malzeme olan kaşe lastiğinden üretim yapılması daha doğru olacaktır. Kaşe lastiği veya benzeri esnek ma- teryallerden üretilen mühürler kolayca kıvrılabildiği için seramik formun hareketine göre, yüzeyde herhangi bir deformasyon oluşturmaksızın uygulanabilir (Resim 10).

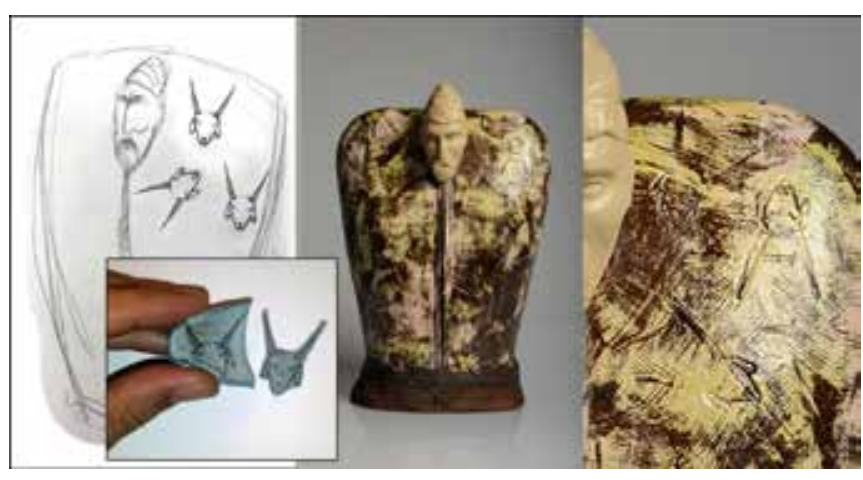

Resim 10. İstenilen doku veya desenler esnek kaşe lastiği ile üretilen mühürler sayesinde eğimli yüzeyler üzerinde deformasyon yaratmaksızın basılabilir. Efe Türkel, "Çoban”Kahverengi şamotlu çamur ve beyaz stoneware, 33,5 x 25 x 15 cm, 2012. (Fotoğraf: Gözde Yenipazarlı Dinler).

Aynı tip kaşe malzemesi ahşap ve benzeri sert bir gövdeye yapıştırılarak geniş yüzeylerde de uygulanabilir. Özellikle madalyon tipinde, her iki yüzeyinde rölyef ve mühür benzeri desenler bulunan pişmiş toprak ürünlerde uygulanması pratiktir. Malzemenin esnek olması sayesinde preslenerek belirli bir sertliğe ulaşmış çamurun üzerine yapılan baskıda deformasyon azalacağı gibi herhangi bir kaydırma hatası, sert malzemeden üretilmiş mühürlere oranla azalacaktır. Bu işlemde çok az miktarlarda organik yağlar mührün üstüne sürülürse, ince detayların olduğu kısımlarda çamurun presleme sonrasında mühre yapışması veya kalıntı bırakması da engellenebilir (Resim 11).

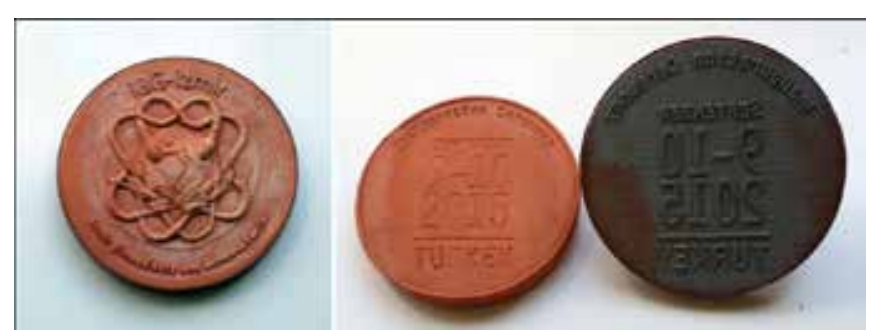

Resim 11. Dokuz Eylül Üniversitesi, İzmir Biyotıp ve Genom Merkezi için tasarlanmış anı madalyonunun ön ve arka yüzü. Kalıpla şekillendirme, kırmızı çamur, çap: $11 \mathrm{~cm}$. (Uygulama: Dokuz Eylül Üniversitesi, Güzel Sanatlar Fakültesi, Tasarım Grubu. Fotoğraf: Efe Türkel). 


\section{Lazer Oyma Makineleri Aracılığıyla Rölyefli Modellerin Oluşturulması}

Lazer oyma makinelerinde işlenmiş materyalleri alçı, kil, ahşap gibi çeşitli malzemelere monte ederek seramiğe uygun kalıplanabilir modellere çevirmek mümkündür. Burada dikkat edilmesi gereken önemli hususlardan biri, seramik çamurunun çeşidine göre kuruma ve pişme küçülmelerinin de göz önünde bulundurulmasıdır. Çalışılacak parçanın boyutları çamurun küçülme oranlarına göre hesaplanarak iki boyutlu olarak vektörel tabanlı çizim yapılabilen yazılımlarda kolaylıkla ölçeklendirilebilir (Resim 12). Özellikle yazı, logo veya kesin ölçülere sahip desenlerin işlenmesinde bu cihazlar mutlak bir hassasiyet sağlayacaktır. Özellikle belirli bir esnekliğe sahip sentetik malzemelerin işlenmesiyle elde edilen parçaların alçı kalıp uygulamalarında kırılma veya desen ihtiva eden yüzeylerde bozulma gibi sorunlar yaşanmayacaktır. Bu tip çalışmalarda dikkat edilmesi gereken noktalardan biri de lazer oyma makinesinde işlenmiş olan materyalin ana modele kuvvetli yapıştırıcılarla yapıştırılması gerekliliğidir. Bu işlem sonrasında modelin alçıdan kalıbı alınarak döküm veya baskı yöntemiyle şekillendirmeye uygun hale getirilir.

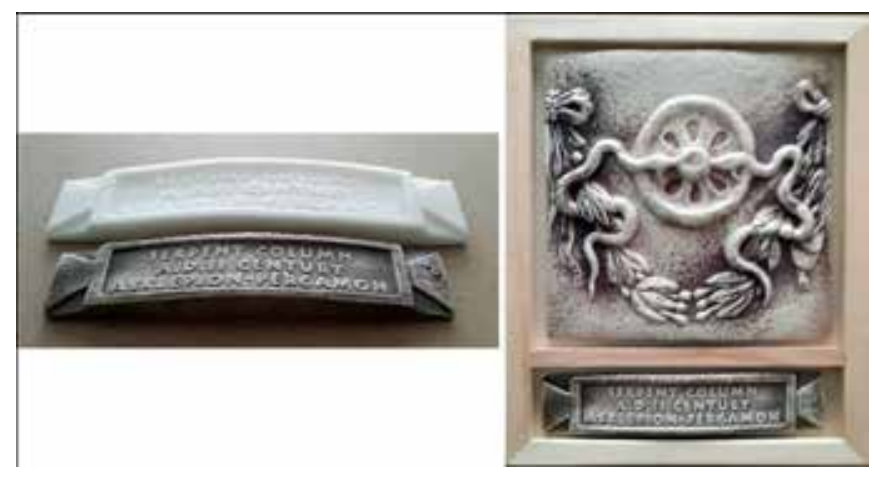

Resim 12.Dokuz Eylül Üniversitesi, İzmir Biyotıp ve Genom Merkezi için tasarlanan ahşap çerçeve içine monte edilmiş seramik plaket. Kile adapte edildikten sonra alçı kalıbı ve silikon modeli alınmış olan tabula ansata ${ }^{7}$ için lazer kaşe lastiğine kazıma yapılmıştır. (Uygulama: Dokuz Eylül Üniversitesi, Güzel Sanatlar Fakültesi, Tasarım Grubu (Fotoğraf: Efe Türkel).

\section{Silindirik Mühürlerin Yapımı}

Desenin seramik yüzey üzerinde devamlı olarak tekrar edilmesi gereken durumlarda rulet olarak da adlandırılan silindirik mühürler kullanılır. Silindirik mühürleri lazer kazıyıcılarla yapmak da mümkündür. Öncelikle yüzeyin işleneceği ölçü ve desenin üzerine oturacağı silindirin alan ve çevre hesapları gibi matematiksel değerler gerekliyse tespit edilir. Bu ölçüler doğrultusunda desen yazılımlarda çizilir ve boyutlandırılır. Daha sonra yumuşak bir malzemeye işlenen desen, ölçülerine uygun silindirik bir objenin üzerine sabitlenerek kullanılabilir (Resim 13).

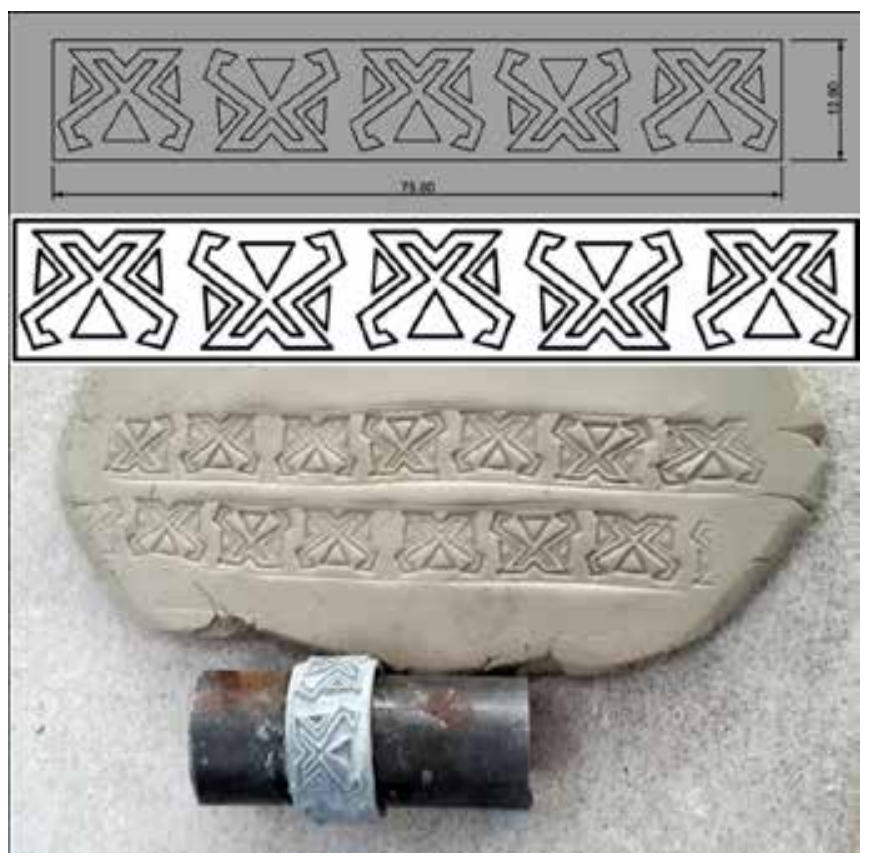

Resim 13. Desen tasarımı bant olarak uygulandıktan sonra lazer kazıyıcılarla işlenir ve silindirik bir yüzey üzerine monte edilerek çamur üzerinde devamlı desenler olarak basılabilir

(Tasarım ve uygulama: Efe Türkel).

\section{Sonuç ve Değerlendirme}

İnsanoğlu nasıl ki kili şekillendirerek işlevsel nesneler üretme ihtiyacı hissettiyse, ürettiğini de elleriyle, doğada var olan nesnelerle veya yaptığı aletler aracılığıyla bezeyerek ona bir kimlik kazandırma veya süsleme ihtiyacını da hissetmiştir. Bunu kimi zaman farklı renk çamurlarla veya pigmentlerle yüzeyi bezeyerek, kimi zaman da kil henüz şekillendirilebilir durumdayken üzerine yaptığı oyuntular, rölyefler, çizgiler ve baskılarla gerçekleştirmiştir. İnsanlığın ateşi bularak toprağı şekillendirip pişirerek sertleştirmesinden bu yana var olan seramik işlevsellik, teknik ve biçimsel açıdan günümüze dek sayısız gelişim 
göstermiştir. Bu gelişim sayesinde teknolojik, sosyal ve sanatsal değişikliklere ve yeniliklere uyum sağlayan seramik, her zaman güncel ve tercih edilen bir malzeme olarak kalabilmiştir. Tüm bu yenilikler seramikte farklı bezeme tekniklerini de beraberinde getirmiştir. Ancak pişmeden önce seramik yüzey üzerine mühürler, ruletler veya farklı araç gereçlerle bırakılmış izler diğer bezeme tekniklerine nazaran daha kalıcı olmuştur. Bu özelliği sayesinde seramik malzeme ticari dokümanların veya gelecek nesillere aktarılmak istenen bilgilerin kayıt altına alınmasında kullanılarak taşınabilir ilk yazılı belgelerin de oluşturulmasını sağlamıştır.

Günümüzde mühürlerin veya seramik yüzeyler üzerine bırakılan izlerin dokümanter amaçla kullanılma gerekliliği olmamakla beraber, sanatçılar veya işletmeler, eserlerinin veya ürünlerinin üzerine mühürlerle kimliklerine ait izler bırakmaktadır. Mühürler, bu yönüyle belgeleyici olma özelliklerini sürdürmektedir. Bunun haricinde seramik yüzeyler üzerinde baskılama sonucu bırakılan izlerin daha çok estetik unsurlar olarak kullanıldığı görülmektedir. Mühürler ahşap, metal, alçı ve benzeri kolay işlenebilir pek çok malzemeden üretilebilmektedir ancak hassasiyet gerektiren çalışmalar için bazen insan elinin becerisi istenen sonuçları elde etmek için yeterli olmamakta veya desenleri mühür üzerine işlemek uzun süreler almaktadır. Düşük maliyetlerde ve hızlı biçimde oluşturulabilen bu çalışmaların kullanıcı açısından avantajları özellikle hassasiyet gerektiren çalışmalarda oldukça fazladır. Yazılımlar ve lazer oyma makineleri, grafik tasarımı gerektiren çalışmalar için de pek çok ihtiyaca cevap verebilmektedir. Özellikle tipografik mühür veya model çalışmalarında yazılımların arşivinde bulunan veya internet ortamından elde edilen çeşitli fontlarla istenilen punto büyüklüklerinde ve düzenli aralıklarda yazılar oluşturulabilmesi mümkündür. Bununla beraber serbest elle çizilen herhangi bir çizim veya fotoğraf yazılımlar aracılığıla piktogram benzeri görüntülere dönüştürebilir. Aynı zamanda yazılıma uyumlu ek programlarla tram baskılı veya gravür etkili görseller de elde edilebilir ve yazılımların sunduğu imkânlar dâhilinde bu gibi örnekler çeşitlendirilebilir.

Lazer kazıyıcılarda şekillendirilen materyallerin seramikteki avantaj ve dezavantajlarını aşağıdaki temel başlık- larla sıralanabilir:

Avantajları:

* Farklı malzemeler üzerine kazıma işlemi yapılabilmesi sayesinde seramik şekillendirme ve kalıplama yöntemlerine uygun sonuçlar elde edilebilmesi,

* Özellikle modellemede el işçiliğine yönelik oluşabilecek sorunları ortadan kaldırabilmesi,

* Zamandan tasarruf,

* Esnek malzemelerle üretilen mühürler sayesinde eğimli yüzeylerde deformasyon yaratmaksızın desen oluşturulabilmesi,

* Esnek malzemelere kazıma yapılabilmesi sayesinde silindir biçimli ruletler yapılabilmesi,

* Sentetik malzemelerin kalıplamada veya yaş çamur üzerinde kullanılırken detaylarında kullanım sayısıyla ilişkili herhangi bir deformasyon oluşmaması.

Dezavantajları:

* Büyük yüzeyli, derin ve özellikle üç boyutlu rölyefli çalışmalarda oluşabilecek maliyet,

* Derin rölyefli çalışmalarda sentetik malzeme kullanılıyorsa, aşırı ısıdan dolayı oluşabilecek deformasyon riski,

* Düşük maliyetli çalışmalarda, desenlerin dik açıyla kazınması ve sonucunda eğimli yüzeylerde kullanılacak rölyeflerin kalıp içinde ters açı oluşturma riskine karşın alçak rölyef olarak kazınması,

* Üç boyutlu desenlerin sadece ahşap, metal gibi esnekliği olmayan materyallerde uygulanabilmesi,

* Çalışma alanında yeterli havalandırma ve iş güvenliği tedbirleri alınmamışsa, sentetik malzemelerin kazınması esnasında atmosfere karışan zehirli gazların solunması,

* Bazı sentetik malzemelerde alçı, çamur ve ahşap malzemedeki gibi tamirat ve tadilat yapılamaması (Kundul, 2013: 191).

Elde üretilmiş mühürlerin veya baskı gereçlerinin etkilerinin, yazılımlar ve çıktıları gerçekleştiren cihazlar 
aracılığıyla kopyalanabilmesiyle, yaratım ve üretim süreci eskiye nazaran farklı bir yol izlemektedir. Bilginin, çok çabuk üretildiği ve tüketildiği bu günlerde sanat eserleri veya tasarımlara ait yaratı süreci de bu hızdan nasibini almakta, her yeni gün farklı uygulama biçimleri hem sanatçı-tasarımcı hem de izleyici tarafından deneyimlenmektedir. Lazer oyma makineleri de çabuk ve titizlikle üretim gerektiren noktalarda kullanıcıya farklı ve yeni tecrübeler yaşatabilecek özellikte tasarım ve uygulama modelleri sunmaktadır.

\section{Notlar}

1- Dolni Věstonice'de (Çek Cumhuriyeti) bulunan figürinlere ve kırık seramik parçalarına ait kalıntılar seramik yapımının başlangıcı olarak tanımlanmışıtır. Burada bulunan figürinler 500 ila $800^{\circ} \mathrm{C}$ arasında pişirilmiş, gündelik kullanım amacıyla yapılmamış, pekişmemiş seramik bünyelerdir (Vandiver, 1989: 1002).

2- Kyushu Adası'nın Batısında yer alan mağaralarda gerçekleştirilen kazılarda bulunan parçalara uygulanan Karbon-14 testleri sonucunda en eski çömlekçilik geleneğinin bu noktada başladığı saptanmıştır. Bu dönem Buz Devri'nin sonlarına tekabül eder ve yine bu dönemde Japon Adası Kuzeyde Sibirya'yla, Güneybatı'da Kore'yle bağlantılidir (Dunn, 1999: 576)

3- Denise Schmandt-Besserat; yazı ve sayımın kökenleri üzerine çalışmış olan Fransız kökenli Amerikalı arkeolog.. 4- Kil tablet üzerindeki yazıların İngilizce tam metin tercümesi için: http://www.britishmuseum.org/ research/collection_online/collection_object_details. aspx? objectId=327188\& partId $=1$

5- 'Bézier curves' ve 'non uniform rational B-splines' olarak bilinen çizgi çeşitleri vektörel çizimlerde kullanılan temel iki tip çizgi çeşididir.

6-https://www.youtube.com/watch?v=W58UjRpXQ9I adresinden cihazın çalışma prensiplerine ilişkin videoları izleyebilirsiniz.

7- Tabula Ansata; antik sanatta kulplu çerçeve biçiminde betimlenen kitabelik (Saltuk, 1993: 171).

\section{Kaynakça}

Coleman, J. E. (1985). "Frying Pans of the Early Bronze Age Aegean". American Journal of Archaeology (89/2): 191-219.

Dunn, M. (1999). “Japanese Ceramics”. The Art of East Asia, ed. Gabriele Fahr-Becker, Cologne: Könemann Verlagsgesselschaft, s: 573-612.

Kundul, M. (2013). Endüstriyel Seramikte Alçı ve Çamur "Şekillen dirme Yöntemleri İstanbul: Biltur Basım Yayın ve Hizmet A.Ş.
Minogue, C. (1996). Impressed and Incised Ceramics. Florida, USA: Gentle Breeze Publishing.

Nicolopoulou, A. (1997). "The Invention of Writing and the Development of Numerical Concepts in Sumeria: Some Implications for Developmental Pschology”. Mind, Culture and Activity, ed.Michael Cole, Yrjo Engestorm, Olga Vasquez, Cambridge University Press: 205-225.

Saltuk, S. (1993). Arkeoloji Sözlüğü. İstanbul: İnkılap Kitabevi.

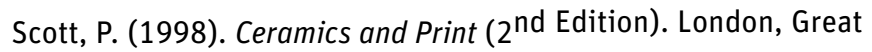
Britain: A\&C Black Publishers Limited.

Shendge, M. J. (1983). The Use of Seals and Invention of Writing. Journal of the Economic and Social History of the Orient (26/2): 113-136.

Vandiver, P. (1989). The Origins of Ceramic Technology at Dolni Věstonice,

Czechoslovakia. Science, New Series (246/4933): 1002-1008.

\section{İnternet Kaynakları}

Epilog Laser

https://www.epiloglaser.com/how-it-works/laser-materialcompatibility.htm (Erişim tarihi: 13/02/2016)

The British Museum

http://www.britishmuseum.org/research/collection_online/ collection_object_details.aspx?objectId=327188\&partId=1 (Erişim tarihi: 11/02/2016)

\section{Görsel Kaynaklar}

Resim 1. İp desenli ve fitillerle bezenmiş derin kap. 69,8 x 41,9 cm. Orta Jōmon Dönemi, M.Ö. 3500-2500. Metropolitan Museum of Art. Arşiv erişim numarası; 1965.268.182. ht t p: //www.metmuseum . org/toah/works-of art/1975.268.182/

Resim 2. Imré Schrammel'in ölü bir kuşun bedenini kil üzerine basarak aktardığı çalışması (http://www.mma.hu/muveszetihirek/-/event/10180/schrammel-imre-keramikusmuveszkiallitasa-szombathelyen)

Resim 3. Kiros Silinidiri, Büyük Keyhüsrev’in (II. Kiros) ilk insan hakları bildirgesi varsayılan metninin yer aldığı pişmiş topraktan yapılmış silindir, M.Ö. 539 ve sonrasına tarihlendirilmiştir. The British Museum. Müze envanter numarası: 90920.

(https://en.wikipedia.org/wiki/Cyrus_Cylinder\#/media/ File:Cyrus_Cylinder_front.jpg) 
Resim 4. Syros'ta bulunmuş, üzeri dalga benzeri spirallerle bezenmiş Kikladik Tava. M.0̈. 2800 - 2300. Atina Ulusal Arkeoloji Müzesi. Envanter numarası: 5058. Fotoğraf: Dan Diffendale (2012)

(https://www.flickr.com/photos/dandiffendale /8245074440/in/album-72157632150547975/)

Resim 5. Bitkisel bir desenle birbirinden ayrılarak resmedilmiş iki kuş figürlü pişmiş toprak yer karosu. Desenler önce mühürle basılmış, daha sonra içi beyaz sıvı çamurla doldurulmuştur. 14 x $14 \mathrm{~cm}$ boyutlarındaki karo 1280 yılında Hampshire Hıristiyan Kilisesi için yapılmıştır. V\&A Müzesi Koleksiyonu. Müze numarası: 1268-1892 (http://collections.vam.ac.uk/item/077386/tile-unknown/)

Resim 6. Dantellerin ve kumaşların kil üzerine bir merdane aracılığıyla çıkarılmasıyla farklı ve deneysel desenler elde etmek mümkündür. Efe Türkel, 'A donkey is always donkey', $25 \times 11 \times 10 \mathrm{~cm}$, stoneware, tuz pişirimi, 2014. Letonya Güzel Sanatlar Akademisi Koleksiyonu. (Fotoğraf: Efe Türkel)

Resim 7. Mürekkepli kalemle kâğı üzerine yapılan logonun dijital ortama aktarılarak vektörel çizime dönüştürülmesi ve mühür uygulaması (Uygulama: Efe Türkel).

Resim 8. Bir fotoğraf aracılığıyla yapılan vektörel tasarımın pleksi malzemeden mühre dönüştürülmesi ve kil üzerine uygulandıktan sonra terra sigillata ile renklendirilmesi (Uygulama: Efe Türkel).

Resim 9. Epilog firmasının, $45 \times 27 \mathrm{~cm}$ çalışma tepsisine sahip mini serisi lazer oyma makinesi.

Resim 10. İstenilen doku veya desenler esnek kaşe lastiği ile üretilen mühürler sayesinde eğimli yüzeyler üzerinde deformasyon yaratmaksızın basılabilir. Efe Türkel, "Çoban”Kahverengi şamotlu çamur ve beyaz stoneware, 33,5 x 25 x $15 \mathrm{~cm}, 2012$. (Fotoğraf: Gözde Yenipazarlı Dinler).

Resim 11. Dokuz Eylül Üniversitesi, İzmir Biyotıp ve Genom Merkezi için tasarlanmış anı madalyonunun ön ve arka yüzü. Kalıpla şekillendirme, kırmızı çamur, çap: $11 \mathrm{~cm}$. (Uygulama: Dokuz Eylül Üniversitesi, Güzel Sanatlar Fakültesi, Tasarım Grubu. Fotoğraf: Efe Türkel).

Resim 12. Dokuz Eylül Üniversitesi, İzmir Biyotıp ve Genom Merkezi için tasarlanan ahşap çerçeve içine monte edilmiş seramik plaket. Kile adapte edildikten sonra alçı kalıbı ve silikon modeli alınmış olan tabula ansata 8 için lazer kaşe lastiğine kazıma yapılmıştır (Uygulama: Dokuz Eylül Üniversitesi, Güzel Sanatlar Fakültesi, Tasarım Grubu. Fotoğraf: Efe Türkel).
Resim 13. Desen tasarımı bant olarak uygulandıktan sonra lazer kazıyıcılarla işlenir ve silindirik bir yüzey üzerine monte edilerek çamur üzerinde devamlı desenler olarak basılabilir (Tasarım ve uygulama: Efe Türkel). 